\title{
INVESTIGACIÓN/RESEARCH
}

\section{LA TRASCENDENCIA FÍLMICA Y EL PROBLEMA DE LO REAL EN LA ESTÉTICA DE HENRI AGEL}

Francisco A. Zurian: Universitat de València (España)

\section{El cine con alma como cine verdadero}

Al esteta fílmico Henri Agel lo que le preocupa es conseguir que más espectadores y realizadores se ocupen de un cine auténtico: realizadores que lo hagan posible y espectadores que sean capaces de vivirlo en sus visionados. Esta visión del cine le llevará a dos implicaciones claras; por un lado, la necesidad de establecer una clasificación cualitativa de las películas, en las que deberán tener preeminencia las películas que posibiliten un "ir más allá", esto es, las obras cinematográficas "espirituales" en el sentido ageliano. Por otro lado, se debe proponer una ética de la realización cinematográfica que estará basada en el auténtico "ser" del cine (que será, el buen cine o cine verdadero) y que conllevará, por parte del realizador, una forma de hacer y del espectador una forma activa (contra la pasividad) de mirar.

Debemos tener en cuenta que estas dos consecuencias están íntimamente unidas en el pensamiento ageliano y que si las separamos -y, por consiguiente, las explicamos separadamente- es únicamente por necesidades de claridad en nuestra exposición.

Hay un universo escondido al que podemos acceder purificando nuestro mirar y nuestro corazón (...). Yo lo que intento es poner al público en 'estado de gracia' o de receptibilidad. Pienso que ese es el papel del cine. A partir de esto el espectador es diferente, ya que el director es algo así como un guía1.

La idea básica es, pues, la espiritualidad y, para conseguirlo, nuestro autor desarrolla una teoría estética, intenta ser pedagógico y divulgador para llegar a más $\mathrm{y}$, para abundar en la claridad de su discurso establece numerosos ejemplos (verdaderas listas interminables de catálogos de realizadores, películas...) distinguiendo entre verdadero cine y pseudo-cine. Si se contempla al cine de este modo, se pueden distinguir dos grados de cine2, un "primer grado" de cine, que sería la mera realidad epidérmica de la imagen y, un "segundo grado" que sería la realidad

\footnotetext{
1 ZURIAN, Francisco A.: "Entrevista con Henri Agel: Por una teoría del cine” en Film-Historia, Vol. I, no 1, 1991, p. $39-41$.

2 Cfr. AGEL, Henri: "El humanismo cinematográfico" en VV.AA. Cine, educadores y educandos, Madrid, Sociedad de Educación Atenas, 1961, pp. 69-70.
} 
espiritual de la imagen 0 , dicho de otro modo, el cine que permite adivinar lo espiritual que en él se contiene por medio de lo sensible3.

El valor de la obra cinematográfica está en hacer que los espectadores capten su "alma", es decir, sean capaces de "desvelar" los significados que pueda esconder en sí misma. El valor de una película dependerá de cómo se realice la expresión artística, esto es, la expresión de la "idea" que el autor quiere comunicar. Lo importante no es, por tanto, la historia en sí, sino cómo ésta se cuente. Si consigue una buena expresión artística el espectador podrá adentrarse en ella y captar su sentido e, incluso, otros diferentes, si no lo consigue será una película superficial, convencional. El medio audiovisual supone esa complejidad de sentidos que operan más clara u oscuramente en la imagen. Podemos invocar su "pureza" icónica si la imagen, si los planos, expresan bien -artísticamente hablando- la historia. De ahí que Henri Agel señale que todos los elementos juegan un papel importante en la realización de la obra cinematográfica y todos se influyen mutuamente puesto que "las distintas posibilidades de expresión de un tema (...) determinan una serie de niveles espirituales, según los diversos elementos puestos en juego respondan a una mayor o menor armonía"4.

De todas formas, como ya apuntamos, los tres factores principales que aseguran la calidad de una película son el guión, la realización y el diálogo e interpretación.

Una película es trascendente cuando nos muestra que su inspiración, su realización, su interpretación alcanzan -en distintos niveles- todos los estratos del público de una manera profunda e irreductible o una simple satisfacción psicológica, afectiva o estética5.

Por todo lo dicho se puede apreciar la razón del preponderante papel del espectador y, para iniciar al espectador, la importancia del educador o "experto", puesto que muchos espectadores no se encuentran en disposiciones de encontrar dichos significados, es decir, no pueden encontrar en la película el fondo de sus significaciones ocultas -alma de la película-, necesitan un aprendizaje perceptivo: aprender a interpretar las películas.

Lo difícil es constatar que no hay reglas para la interpretación, sólo el director proporciona en la obra cinematográfica una serie de claves que son, precisamente, las que hay que aprender a captar de ese texto que es la película. Tal vez la única regla sea la necesidad -imperiosa- de huir del cine "escape", de ese cine que lo único que hace es sumir al espectador en la pasividad. El criterio básico, pues, podría ser este: huir del cine como instrumento de un escapismo vacío y anulador de una concepción cultural y de una experiencia estética.

El cine no es más que un opio que permite a las rechazados, a los desarraigados, a los insatisfechos de toda laya, abandonarse a una

\footnotetext{
3 Cfr. ZURIAN, Francisco A.: "Entrevista con Henri Agel: Por una teoría del cine” en Film-Historia, Vol. I, no 1, 1991, p. 37.

$4 \quad$ AGEL, Henri: ¿El cine tiene alma? Madrid, Rialp, 1958, p. 30.

5 AGEL, Henri: ¿El cine tiene alma? Madrid, Rialp, 1958, p. 31.
} 
segunda vida, a una existencia prestada, que discurre al margen de la vida cotidiana: los adultos, al igual que los jóvenes, experimentan sensaciones voluptuosas, idílicas o brutales, que a la larga vienen a integrarles en una especie de mundo ideal más hermoso, más excitante que el mundo de la vida ordinaria: mundo mítico, el reino de las quimeras6.

Evidentemente, en esta perspectiva, se entiende cómo para Agel todas las películas situadas en el primer grado serán películas malas -telúricas, sin alma- y sólo aquellas situadas en el segundo grado serán auténtico y verdadero cine, las otras serán:

alimentos tóxicos llamados "films" cuyo efecto, comparable al de un narcótico, es capaz de disolver las facultades espirituales, de mantener una semi-estupidez y de imponer ciertos mitos a la vez engañosos y disolventes (...); obras mórbidas, producto de cerebros enfermos o trastornados, exaltaciones patológicas de las oscuras complacencias del inconsciente; las cintas pseudo-psicoanalíticas, destinadas a agitar del modo más sospechoso el organismo de los espectadores7.

Nuestro autor da la siguiente definición de la tipología que establece un primer "grado" que va a la realidad espiritual de la imagen. Cine con alma, verdadero cine, o, también, cine sagrado (en palabras de Agel "el verdadero cine es una purificación de lo real's).

El cine, cuando puede disponer de sus poderes para convertirse a su vez en una especie de oficio o de celebración, merece el nombre de cine sagrado (...).

El cine verdadero es el que desemboca en lo cósmico (...). Porque el cine, como signo de realidad múltiple, tiene que dar una visión múltiple y en toda su amplitud y profundidads.

Y un cine, centrado en la realidad epidérmica de la imagen, al que podríamos denominar "Cine telúrico", pseudo-cine, o, cine falso ("tres cuartas partes del cine es grosero, vulgar"10).

\footnotetext{
$6 \quad$ AGEL, Henri: El cine. Bilbao, Desclée de Brouwer, 1957, p. 19.

7 AGEL, Henri: "El cine-club en el Instituto" en VV.AA. Cine, educadores y educandos, Madrid, Sociedad de Educación Atenas, 1961, p. 173.

8 ZURIAN, Francisco A.: "Entrevista con Henri Agel: Por una teoría del cine” en Film-Historia, Vol. I, n 1, 1991, p. 40.

9

p. 40.

10

ZURIAN, Francisco A.: "Entrevista con Henri Agel: Por una teoría del cine” en Film-Historia, Vol. I, no 1, 1991,

ZURIAN, Francisco A.: "Entrevista con Henri Agel: Por una teoría del cine” en Film-Historia, Vol. I, no 1, 1991,

p. 40.
} 
Aquellas películas que no han sabido estructurar un alcance religioso en términos suficientemente expresivos no merecen, a nuestro juicio, cualesquiera que sean sus posibles méritos, figurar en la categoría del cine sagrado 11.

El cine que no me gusta es un cine material, sin "más allá", sin alma, un cine meramente telúrico. Las grandes obras tienen "prolongación" en lo inmaterial (...). Muchos sólo se quedan a un primer nivel. Hay una frase de San Pablo que es la clave: "lo vemos todo en enigma, como en un espejo"; para mí esta frase define mi idea del cine12.Así pues, para Agel, la calificación del cine como bueno, esto es "con alma", conlleva una apertura total del espectador al mundo -a la realidad total, no solamente material- propiciada por la película. De este modo podemos ver cómo el ser humano está "invitado" al mundo por el arte, en el cual encontramos un sentido, nos revela un mundo "oculto" para el simple análisis lógico.

Es lo que nuestro autor denomina manifestación o, mejor, epifanía de lo sensible, puesto que el sentido es algo que un objeto posee e irradia naturalmente, al contrario de la significación que es impuesta por el hombre a un objeto. De ahí se nos abre la vía trascendente para el hecho cinematográfico y su experiencia estética. $Y$ esto lo consiguen las buenas obras cinematográficas porque no están cerradas sobre sí mismas sino que son obras abiertas que posibilitan diversas lecturas, provocando una reacción afectiva. Obras que "ante todo, se preocupan de resultar veraces, trascienden todas las categorías y son, a la vez, una narración, un testimonio, un poema, una meditación"13.

La complicación vendrá de la mano del canon de esa medida. ¿Cuál es el criterio que pondrá a unas películas bajo el rótulo de "Cine telúrico" y otras bajo el de "Cine con alma"? No es fácil establecer ese canon o regla. No hay manera veraz de hacer intersubjetivo lo desconocido. Y Agel pretende dar carácter universal a algo meramente subjetivo: su criterio. En la cita anterior: "el cine que no me gusta"; otras veces el criterio es "me muestra trascendencia" 14.

El mismo Agel se lo cuestiona y llega a preguntarse " ¿es esto mostrarse demasiado subjetivo?"15. La contestación es bastante obvia: sí que resulta "demasiado subjetivo", especialmente porque sus razones sobre la trascendencia -o no- son limitadas y siempre muy apoyadas en la propia experiencia (en su caso, experiencia de un "experto"). Como botón de muestra transcribimos las razones que da sobre unos "malos" intérpretes:

No vemos traslucir el alma a través de estos otros intérpretes, dignos por otra parte de la mayor estima (...). Se podría llegar a pensar que todas ellas [a las que antes había calificado de 'muñecas' americanas] ejercen una singular fascinación en la medida en que parecen estar desprovistas 
de alma..., pero esto no es más que la hipnosis que provoca la vacuidad, la estética de la nada16.

Agel reconoce que su postura es subjetiva que, efectivamente, no busca la objetividad pero cree que esto debe ser de este modo, ya que, después de todo, el mundo que el cine nos transmite tampoco lo es. Agel, pues, reconoce el subjetivismo latente en esta idea de clasificación cualitativa del cine17, que solamente puede establecer como "medida" la capacidad de "apertura" de la obra cinematográfica. Se trataría, una vez más, de la ya tratada conjunción espiritualidad-ética que será la que dé razón de un auténtico y verdadero cine "total"18.

Es sólo cuando consideramos al cine en su totalidad que encontramos su verdad humana. Las intenciones del autor son valiosas solamente cuando aparecen modificadas y moldeadas en una simbiosis con el mundo. El cine, lejos de ser un frío registro del mundo, es un registro de esa relación simbiótica entre intención y resistencia, entre autor y material, entre mente y materia. El público solo (incluyendo al autor cuando vuelve a ver su propio film) transforma ese aburrido registro físico en una vibrante realidad humana, experimentando ese drama de la mente y la materia19.

Además nuestro autor se plantea que, al final, de lo que se trata es de mantener una conversación "sin rigurosa disciplina alguna" 20 , sino, más bien contribuir a una cultura más humana y, esto para Agel significa, más espiritual. El rol del cine está ahí, en la cultura, como catalizador de civilización, sin dogmatismos y con un sentido abierto pero, al mismo tiempo, depurando lo malo que en él pueda existir.

El cine es ese vehículo privilegiado de un verdadero humanismo, que debe ser total, vivo y vertical, esto es trascendente. El hecho cinematográfico se presenta como un medio idóneo para conseguirlo.

El cine, por esencia, prende al hombre de manera total en el mundo.

El cine, por esa especie de universalidad, de catolicidad que propone, incita a la apertura, a la dilatación (...). El cine puede ofrecernos más todavía. No es solamente la reproducción de ciertos espectáculos que vemos a nuestro alrededor, no es solamente la encarnación de ciertas

16 AGEL, Henri: ¿El cine tiene alma? Madrid, Rialp, 1958, p. 36.

17 Esto nos contestaba Henri Agel a nuestra observación sobre la latente subjetividad de su enfoque: "Es verdad, pero ese subjetivismo es a nivel humanista, laico. A un nivel sobrenatural desaparece el subjetivismo, porque en esa instancia todo es signo: para una persona que cree todo es signo... Supongo que mi inclinación personal es más artística que filosófica..." (ZURIAN, Francisco A.: "Entrevista con Henri Agel: Por una teoría del cine" en Film-Historia, Vol. I, n 1, 1991, p. 40).

$18 \quad$ Cfr., p.e., "El cine como mediación" en "Cine y presencia personal", dentro del libro colectivo AGEL, Henri y AYFRE, Amédée: Cine y personalidad, Madrid, Rialp, 1963, pp. 64-68.

19 ANDREW. Dudley J.: Las principales teorías cinematográficas, Madrid, Rialp ( $2^{\circ} \mathrm{ed}$. aumentada; $1^{\mathrm{a}}$ ed. en Barcelona, Gustavo Gili, 1978), pp. 292.

20 AGEL, Henri: ¿El cine tiene alma? Madrid, Rialp, 1958, p. 38. 
verdades, ya que puede llegar bastante más lejos y, como un poema, como un cuadro, puede alcanzar un valor simbólico21.

Agel preocupado por esta culturización del hecho cinematográfico, tan sometido a los vaivenes de la industria y de la ideología22, va ha distinguir, además, entre un cine de "significación" -caso, por ejemplo, de Eisenstein- y un cine de "contemplación" Dreyer, Flaherty, Rossellini, Mizoguchi, Renoir...-, en el que la "sensación" del mundo aparece lentamente y sin abrumar. Para nuestro autor lo que deben hacer los realizadores no es una sintaxis sino que deben leer el sentido del mundo.

En sus grandes obras una multiplicidad de sentidos se condensa en poderosas imágenes, que poseen la fuerza de la trascendencia porque es la naturaleza y no el hombre la que habla desde la pantalla23.

Es fácilmente perceptible apreciar en la obra ageliana un pensamiento que está basado, principalmente, en sus propias intuiciones y apoyado en las obras en las que ve sus ideas perfectamente plasmadas. De este modo realiza su teorización. Por lo tanto se trata de un análisis de espectador y de un análisis de los "grandes" autores. De ahí saca sus ideas que, sirviendo de un esquemático cuerpo teórico y metodológico, le sirven para expresar lo que él lleva dentro de sí, su idea de trascendencia, de cine con alma.

El final de la travesía [ageliana] es la trascendencia de unos pocos films privilegiados, de qualité, una trascendencia que conlleva un reduccionismo solapado pero voraz ya que "reduce la realización y el espectáculo del cine a un portal hacia el más allá, dejando fuera de su foco todas las condiciones comunes y el trabajo que supone el proceso del cine" 24.25

\section{La espiritualidad fílmica como estética de la sobre-realidad}

Dicho sentido de trascendencia persigue descubrirnos la espiritualidad de la que el hecho cinematográfico es capaz. No se debe entender en un sentido necesariamente religioso. Para él espiritual es lo más profundo del ser humano, su ser mismo. Tiene mucho que ver con un sentido humanista y poético de la vida. Sería el alma, el "trasfondo" de lo meramente aparente, esto es, físicamente aparente, el sentimiento de lo profundo, de lo auténtico y de lo más humano que la persona tiene.

\footnotetext{
21 AGEL, Henri: "El humanismo cinematográfico" en VV.AA. Cine, educadores y educandos, Madrid, Sociedad de Educación Atenas, 1961, pp. 66-67.

22 Cfr. AGEL. Henri: El cine. Bilbao, Desclée de Brouwer, 1957, pp. 20-24.

23 ANDREW. Dudley J.: Las principales teorías cinematográficas, Madrid, Rialp ( $2^{\circ} \mathrm{ed}$. aumentada; $1^{\mathrm{a}}$ ed. en Barcelona, Gustavo Gili, 1978), p. 288

24 ANDREW. Dudley J.: Las principales teorías cinematográficas, Madrid, Rialp ( $2^{\circ}$ ed.aumentada; $1^{\mathrm{a}}$ ed. en Barcelona, Gustavo Gili, 1978), p. 239/291.

25 ZURIAN, Francisco A.: "Lo real, lo imaginario y lo insinuado. Notas en torno a Henri Agel" en Quaderns de Filosofia i Ciència, nn. 13-14, 1988, p. 172.
} 
Es el sentimiento, indistintamente religioso o laico, de que hay algo inviolable en el hombre, un punto puro, un centro de vida que ni la degradación, ni la desesperanza, ni la tiranía consumen jamás del todo; algo cuyo culto debe asegurar y preservar el hombre; algo donde encuentra el respeto de sí mismo y el poder de rehacer sus fuerzas incesantemente. Sin ello todo se envilecería, todo perdería su sentido, todo se disolvería en la incoherencia y en la nada26.

Para él sería equiparable a una visión "metafísica" aunque con algunas salvedades pues no son sinónimos los conceptos "sobrenatural" y "metafísica", pese a que muchas veces, de forma un tanto confusa, los equipara, véase, por ejemplo, el mismo título de Métaphisique du cinéma cuando de lo que habla es de dicho intento de mostrar el "alma" del cine, su "espiritualidad" 27.

Juego con todos los sentidos del término "alma". Es difícil tener en el Cine una teoría monolítica. La palabra esencial, importante, es "espiritual". Ejemplos de esta forma de ver y entender el Cine son Bresson, Tarkovski... Lo que sucede es que una teoría de estas características es muy difícil, ya que el Cine no es algo del todo palpable...."28.

Podríamos decir que el sentido de "espiritual" para Agel es la caracterización -y constatación- de aquello que hay más allá de la mera realidad física y que es la máxima realidad, como su esencia y, en el cine, aquello que se descubre como su pleno sentido. El cine es un lugar privilegiado de los sentidos, de los símbolos, de los mitos y esto, pide una ontología, una metafísica. Citando expresamente a Jean Mitry, Agel propone unas "notas" de lo sobrenatural: "la persistencia, la identidad del ser; sentimos la eternidad 29 .

Por lo tanto se deben entender las expresiones cine "espiritual", "con alma", "sobrenatural", "sobre-real", etc., como un cine que nos ayuda a trascender la mera imagen, a ir "más allá de lo físico", a no quedarnos en la superficialidad de la mera imagen, a encontrar el profundo sentido en la plena interioridad y exterioridad que supone la trascendencia de la materialidad eso sí, sin renegar de ella, entendiéndola como el soporte desde donde nos es posible arrancar el "vuelo metafísico" hacia una contemplación mayor.

El cine, cuando sabe disponer de sus poderes para convertirse a su vez en una especie de oficio o de celebración, merece el nombre de cine sagrado30.

26 Jean Claude Renard "Retour au sacré" en La Nef, juio-julio 1951 sic AGEL, Henri: El cine y lo sagrado, Madrid, Rialp, 1960, p. 14.

27 AGEL, Henri: Métaphisique du cinéma, París, Petite Bibliothèque Payot, 1976.

28 ZURIAN, Francisco A.: "Entrevista con Henri Agel: Por una teoría del cine" en Film-Historia, Vol. I, n 1, 1991, 
Pero, ¿cuáles son esos poderes? Evidentemente el poder de la imagen y, con ella, el oficio -el saber hacer- y la tecnología. Es la imagen la creadora de esa ilusión de realidad que, a la vez, origina esa sobre-realidad que es como la esencia de lo cinematográfico.

La imagen trasciende en tanto que imagen y puesto que es imagen esta realidad de la que es imagen: la representación se convierte de alguna manera en el signo concreto -la señal- de lo que ella representa, un analogon que 'cristaliza' todas las virtualidades, todas las 'facultades de ser' de lo real representado31.

Es decir, ante la imagen cinematográfica el espectador toma conciencia de la realidad que se organiza en ella descubre esa realidad que no le era visible, muchas veces por lo cotidiano que resultaba y su consecuente acostumbramiento, de este modo alcanzamos a des-cubrir esa realidad en la imagen como si fuera realidad ella en sí misma. Produciendo esa paradoja de una realidad que es irreal o de una realidad que parece sobre-real.

Esta operación tiene en sus efectos, sin duda, algo de mágico y fascinante, pero este algo mágico y fascinante revela los fenómenos de la percepción y en modo alguno un "en sí" metafísico32.

De ahí que Mitry no pueda por menos de criticar la postura "metafísica" de Agel, puesto que confunde "espiritual" o "alma", es decir ese, según Mitry, supuesto "más allá" de los fenómenos con un simple "más allá" de las apariencias.

O mejor dicho, una apariencia nueva nacida de un modo de aprehensión no habitual. Es, si se quiere, un "más allá" de las aprehensiones (y de las comprensiones) inmediatas de la conciencia: percibimos lo que un ojo aunque sea mecánico- ha percibido con anterioridad, lo que una imagen ha estructurado antes; el dato de una percepción que no es la nuestra, de un esquema organizador que no es nuestra conciencia33.

Para Mitry, se trata, pues, de un problema psicológico y no metafísico. Entre el mundo real y el espectador está la película. Se trata, por lo tanto, del hecho de que lo real cinematográfico es un real mediatizado.

Por mucho que insistamos en este punto nunca será suficiente en un tiempo en que se nos habla del "cine verdad", como si el cine tuviera el poder de registrar una "verdad en sí", que nos sería revelada por él; verdad de la que antes convendría demostrar que existe34.

\footnotetext{
31 MITRY, Jean: Estética y psicología del cine, Vol. 1: "Las estructuras”, Madrid, Siglo XXI, 1986, p. 150.

32 MITRY, Jean: Estética y psicología del cine, Vol. 2: "Las formas", Madrid, Siglo XXI, 1986, p. 7.

33 MITRY, Jean: Estética y psicología del cine, Vol. 2: "Las formas", Madrid, Siglo XXI, 1986, p. 7.

34 MITRY, Jean: Estética y psicología del cine, Vol. 2: “Las formas”, Madrid, Siglo XXI, 1986, p. 7.
} 
Para Agel, empero, "lo fundamental del cine es la idea de adivinación de lo espiritual en lo sensible"35. Lo que a él le interesa es ese valor de la imagen capaz de expresar lo que para Mitry no es más que un efecto psicológico al que no hay que darle un estatuto metafísico, él tiene interés por "el realismo poético, el realismo irrealista, puesto que el Cine es una paradoja; el Cine es, al mismo tiempo, realista e irrealista"36, que es capaz de mostrar no lo irreal, sino lo que está más allá de lo meramente visible 37.

No es la realidad lo que el cine nos ofrece, sino una realidad multiplicada, (...) una especie de superrealidad 38 .

El hecho cinematográfico es capaz de llevar toda la "realidad" que nos muestra al máximo plano de su significación y nos presenta algo que no es "palpable" de suyo pero lo muestra, lo aprehendemos y, así, lo podemos conocer, lo podemos vivir y, de este modo, nos enriquecemos.

Los excepcionales medios de que dispone el séptimo arte (movimiento de cámara, encuadre, diversidad de planos, gamas de luces, graduación del ritmo, realce de cualquier detalle), estos medios (...) tienen por objeto el poder conferir a todos los seres, a todos los objetos, a todos los paisajes recreados, a todos los motivos psicológicos, a todos los valores morales, una especie de "sobrerrealidad", por la cual todas las características de la obra creada son llevadas al mayor plano de su significación39.

Nos resalta lo ordinario, nos revela el mismo cosmos, nos hace viajar a lugares recónditos y conocer otras formas, otras culturas. Nos permite, en definitiva entrar en comunicación -en comunión- con toda la humanidad. Es el poder de trascender la imagen. Como dice Agel, el poder de transfiguración, que consiste en el des-ocultamiento que se debe operar en la contemplación de la obra cinematográfica. Un des-ocultamiento que des-cubre lo verdadero, su último sentido, su realidad más plena, lo trascendentalmente real.

La técnica del cine, en manos de artífices verdaderamente enamorados de su oficio, eleva todas las características de la creación cinematográfica a su más alto nivel de significación: funde, en una armonía singular, realismo y poesía, ya que, en el instante mismo en que capta los reflejos o los ecos del mundo real, los traspone por el hecho mismo de su

\footnotetext{
35 ZURIAN, Francisco A.: "Entrevista con Henri Agel: Por una teoría del cine” en Film-Historia, Vol. I, nº 1, 1991, pp. 36-37.

36 ZURIAN, Francisco A.: "Entrevista con Henri Agel: Por una teoría del cine" en Film-Historia, Vol. I, n 1, 1991, p. 39.

37 Cfr. ZURIAN, Francisco A.: "Lo real, lo imaginario y lo insinuado. Notas en torno a Henri Agel" en Quaderns de Filosofia i Ciència, nn. 13-14, 1988, p. 171.

38 AGEL, Henri: "El cine, nueva dimensión" en VV.AA. Cine, educadores y educandos, Madrid, Sociedad de Educación Atenas, 1961, p. 19.

39 AGEL, Henri: ¿El cine tiene alma? Madrid, Rialp, 1958, p. 20.
} 
aprehensión visual y sonora a otro plano de realidad, dándoles así una segunda existencia. Se ha dicho con frecuencia de la poesía que era, en el sentido químico de la palabra, un "revelador" de la realidad; tal afirmación tiene mucho más valor tratándose del cine. El simple hecho de captar la realidad, de encerrarla en una cámara cinematográfica, de proyectarla sobre una pantalla (...) da a esta realidad una dimensión, una consistencia y una gama de sugerencias privilegiada 40.

Agel establece distintos "grados de transfiguración" de la realidad gracias a la técnica cinematográfica41, que van desde la transcripción del mundo exterior a una película que exige su relieve y modifica su color al encuadre de una fracción determinada de la realidad en un espacio riguroso que provoca un modo de percepción estructurada, netamente distinta de la realidad cotidiana. También la continuidad del desarrollo fílmico, cuyos fundidos se oponen, por su fluidez, a las puntuaciones discontinuas del libro, de la pieza de teatro y de la vida cotidiana produciendo un sentimiento casi irreal de elasticidad. $O$, también, la organización del tiempo según cierta elección de planos y duraciones precisas para cada plano.

El hecho de disponer orgánicamente el desarrollo de una escena, primero en una orquestación más o menos analítica de planos y movimientos de cámara, luego en función de una curva rítmica sometida a la voluntad del director, constituye un factor de diferenciación cuyos dos componentes se armonizan y se fortifican42.

Además, la presencia del director de la película en la elección de encuadres, ángulos de toma, iluminación, montaje, etc., asegura que señale el estilo, que es un factor determinante a la hora de conseguir esa transfiguración.
Así llegamos a concluir que cuanto más perfeccione el cine su propio lenguaje, tanto más parece llamado a trascender la realidad (...). El cine sería entonces [es decir, cuando sea de verdad un cine con alma] la expresión más actual y más viva de una magia que, para unos no estaría demasiado lejos de lo que se considera magia negra, mientras que para otros desembocaría en lo espiritual e incluso en lo religioso43.

Para Agel lo espiritual es algo envolvente de toda la realidad humana, sentimientos, símbolos, religión. La persona no solamente es una corporeidad y, por tanto, una materialidad, sino que también es espiritual. El ser humano es trascendente por ser espiritual. Se puede sobre-poner a sí mismo, a su propia materialidad. La experiencia nos muestra esta realidad espiritual de la persona, baste reparar en su capacidad de enamoramiento, su sentido de la intimidad, su pudor, sensibilidad o la misma comunicabilidad humana por el lenguaje. 44

\footnotetext{
$40 \quad$ AGEL, Henri y Geneviève Agel: Manual de iniciación cinematográfica, Madrid, Rialp, 1958 (3ªed. 1965), p. 31.

41 Cfr. AGEL, Henri: El cine. Bilbao, Desclée de Brouwer, 1957, pp. 132ss.

42 AGEL, Henri: El cine. Bilbao, Desclée de Brouwer, 1957, pp. 132-133.

43 AGEL, Henri: El cine. Bilbao, Desclée de Brouwer, 1957, pp. 134-135.

44 Cfr. STEINER, George: Presencias reales. ¿Hay algo en lo que decimos?, Barcelona, Destino, 1991, pp. 14, 111$113,164,121,124,149,253$ у 272-277.
} 
Lo sagrado se define, pues, por relación a esos dos polos, que son (...) de una parte, la trascendencia; de otra parte, lo que es opuesto, lo natural, lo cotidiano, (...) digamos, la inmanencia45.

La inmanencia ha expulsado a la trascendencia, a menos que se pueda hacer resurgir un auténtico carácter sagrado de esta misma interiorización46.

El siguiente paso de nuestro recorrido será tratar de analizar ese sentido de trascendencia que nos habla y nos lleva a lo sagrado en la contemplación del hecho cinematográfico como fenómeno cultural y estético47.

Podríamos resumir todo esto en una definición nueva de arte, más dinámica, más estrechamente relacionada con sus misiones operatorias, con los medios de su acción sobre el espectador, y así diríamos: el arte (...) consiste en encaminarnos hacia una impresión de trascendencia con relación a un mundo de seres y de cosas que nos ofrece únicamente por medio de una acción concertada de 'qualia' sensibles, sostenido por un cuerpo físico dispuesto con vistas a producir tales efectos48.

Agel participa de esta idea 49 e intenta llevarla al cine. En resumidas cuentas esa sería su teoría del cine "con alma". De este modo, sería cine con trascendencia, incluso, "sobrenatural" (en terminología ageliana), aquel que condujera al ser humano a dar lo mejor de sí, que le significara plenamente como persona, que le llevará a la contemplación de lo que es, más allá de la mera materialidad y lo "depositase" en el espíritu. Pero, aunque pudiera parecer lo contrario, no se trata, de suyo, de un cine de carácter religioso o clerical.

Hay que separar absolutamente el cine sobrenatural del clerical. Un director de cine agnóstico, pero cuyo ojo ve más allá, podrá hacer un cine verdaderamente sobrenatural; pero un católico con un ojo mediocre hará mal cine. Hay que alejarse del simple naturalismo e ir a la interioridad. Tal vez por ello sea difícil aprehender y explicar a un nivel meramente teórico el Cine; se necesita la práctica, conocer al público50.

Lo que evidentemente será es un cine que no descarta un punto de vista metafísico.

45 AYFRE, Amédée: El cine y la fe cristiana, Andorra, Casal i Vall, 1962, p. 118.

46 AYFRE, Amédée: El cine y la fe cristiana, Andorra, Casal i Vall, 1962, p. 122.

47 Cfr. AGEL, Henri: Poétique du cinéma, París, Ed. du Signe, 1973, 61ss.

48 SOURIAU, Etienne: La correspondencia de las artes: Elementos de estética comparada, México: F.C.E., 1986 (1 ${ }^{a}$ ed.: 1965), p. 90.

49 Cfr. AGEL, Henri: Estética del cine, Buenos Aires, Eudeba, 1962 (2ªed. 1968), pp. 5-6.

50 ZURIAN, Francisco A.: "Entrevista con Henri Agel: Por una teoría del cine" en Film-Historia, Vol. I, no 1, 1991, pp. 40-41. La cursiva, en esta declaración de Agel, es nuestra. 
reconocer lo sagrado en el mundo exige que hayamos tomado conciencia del misterio ontológico51.

O se descubre primeramente el ser de las cosas o es imposible arrancar a esa realidad su ámbito anímico puesto que éste está anclado en su mismo ser. Se trataría, por lo tanto, de plantearse su ser para, a través de él, descubrir su alma.

Decir, como Amédée Ayfre o como Bazin [o el mismo Agel], que en la imagen cinematográfica 'el misterio del ser está copresente' significa suponer la revelación sui generis de una realidad trascendente por el mismo misterio de la cámara52.

Para Agel, la imagen "encierra en sí" ese universo de posibilidades. El espectador lo que tiene que hacer es descubrirlo. Visto de este modo Agel puede establecer tres posibles tipos de cine con alma o sobrenatural:

podemos imaginar tres modalidades cinematográficas de expresión de lo sagrado: ante todo, la transformación de lo real hasta la ascesis (...). Después, las películas arraigadas en un folklore vigorosamente acentuado (...). En tercer lugar, viene la captación total de "acontecimientos humanos concretos en los cuales está copresente el misterio entero del universo" 53 , la previa posición de limitarse aparentemente a un simple informe que deja al espectador libre para discernir en lo humano la presencia de lo sagrado54.

El primer tipo corresponde al cine que es capaz de transfigurar la realidad concreta de la imagen y situarnos en un plano más elevado de lo espiritual que es el, además, el plano más real. Tan real que es, como hemos visto, sobre-real, sobre-natural, es el cine-poesía, el realismo-poético, el realismo-irrealista. Realismo irrealista en cuanto no atado a la "realidad" inmediata y material. Es irrealista no porque muestre lo irreal sino porque muestra lo que está más allá de lo meramente visible, ese universo oculto tras la imagen que necesita del espectador para ser revelado. $\mathrm{Y}$, además, cada vez que el espectador lo haga, podrá profundizar más o llegar a otros mundos, pues siempre es posible hacer una nueva lectura de la película y, cada nueva visualización es una nueva "lectura" que nos hace vivir un mundo nuevo cargado de sentido.

La segunda caracterización hace referencia a las raíces profundas del ser humano concreto. Las raíces de una persona, de una comunidad, están compuestas de un conjunto de "materialidades" (tradiciones, lenguaje, tópicos, maneras de hacer, decir, celebrar, etc.) pero, en el fondo, tienen poco que ver con la materialidad misma sino que la trascienden: es una ayuda para situarse en el plano de la comunicabilidad interpersonal que sobrepasa el espacio-tiempo determinado en el que se vive y conecta, por vía espiritual, con todos los antepasados, con lo que realmente se es. Se puede decir que, en el fondo, el "tema" del cine (como de cualquier arte) es el

51 CHENU, Joseph: Le thèâtre de G. Marcel et sa signification mètaphysique, Aubier, 1948; sic AYFRE, Amédée: Cinéma et mystère, París, Cerf, 1969, p. 121.

52 MITRY, Jean: Estética y psicología del cine, Vol. 2: "Las formas", Madrid, Siglo XXI, 1986, p. 506.

53 Amédée Ayfre, "Neo-Réalisme et Phenomenologie" en Cahiers du Cinéma, 1952, n. 17.

54 AGEL, Henri: El cine y lo sagrado, Madrid, Rialp, 1960, p. 26. 
hombre, el ser humano en todas sus dimensiones y ámbitos. El arte es una "celebración" 55 que el hombre ofrece a alguien para comunicarle algo, un sentimiento, una experiencia, unas ideas. Siempre es con vistas a ofrecer esa obra a alguien, como regalo, como donación, como un ejemplo de comunión.

Todo lo humano interesa al hombre, todo ello es materia de oblación y de comunicabilidad: la vida y la muerte, sus sentimientos y amores, sus raíces y tradiciones, sus tristezas y alegrías. Como mostraba Agel, en el segundo grado de sobrenaturalidad en el cine, el folklore, entendido como esa manifestación de las raíces de lo humano en un espacio-tiempo, es portador de espiritualidad, por ello:

Todo cine nacional alcanza a transmitir su mensaje repleto de espiritualidad a fuerza de hundirse lo más profundamente posible en el terruño de su propio país56.

A través del cine ( $\mathrm{y}$ de cualquier arte, repetimos) se puede ver la aventura humana, su existencia con todo lo que ella acarrea.

Siendo el arte un artefacto humano que explicita la persona en un espacio-tiempo determinado, está también sujeto, como tal, a las influencias de la razón técnica inherente al momento que vive. Pero, de otro lado, por su propia condición, el arte es capaz de trascender esa influencia y, además, dar sentido al quehacer del ser humano por su especial uso del símbolo. Este abstrae y plasma las trasformaciones que se realizan en el interior del ser humano, permitiendo su expresión y comunicación, puesto que son medios de interiorizar el mundo exterior y de exteriorizar el propio mundo interior.

El arte permite, de este modo, transmitir una gran cantidad de información, más, incluso, de lo pensado por el propio artista, puesto que el receptor-espectador completa con sus propios parámetros y vivencia interior lo dado en la obra de arte. Esto permite al arte entablar una real comunicación tanto con lo pasado como con lo futuro, en un continuo tiempo presente, en un aquí y ahora cultural57.

Estas tres modalidades cinematográficas de expresión de lo sagrado, como se ve no son otra cosa que aspectos de la misma vida humana e, igual que ella se dan, la mayoría de las veces entrelazados. En tercer lugar, nos señala Agel, tendríamos la obra centrada en un episodio humano concreto pero que, a pesar de su fuerte anclaje en un hic et nunc concreto, limitado y simple, nos puede hacer caer en la

\footnotetext{
55 Tesis defendida especialmente en AGEL, Henri: Un art de la célébration. Le cinéma de Flaherty à Rouch, París, Cerf, 1987.

56 AGEL, Henri: ¿El cine tiene alma? Madrid, Rialp, 1958, p. 73.

57 ZURIAN, Francisco A. y ZARCO, Alejandro "El arte y la cultura tecnológica" en Quaderns de Filosofia $i$ Ciència, nn. 21-22, 1993, p. 22.
} 
cuenta de un hecho más universal que conecta con una más amplia cosmovisión. De lo concreto a lo general, de lo pequeño a lo más grande, a lo universal 58 .

Una mano que nos gusta estrechar y besar, nos emociona asimismo porque viene de muy lejos y porque a la forma y a la seducción de sus dedos han colaborado humildemente el big bang, el Cuaternario y las migraciones de los hunos por las estepas de Asia59.

El cine así entendido nos abre a la intimidad de lo humano y, al mismo tiempo, a lo cósmico. Por todo ello el cine da la posibilidad de un verdadero conocimiento del mundo60. Da una nueva visión, una nueva dimensión. Es por ello que el cine puede ser el vehículo idóneo para un nuevo humanismo; un humanismo que tenga vocación de ser "total, vivo, vertical"61.

El cine, por esencia, prende al hombre de una manera total en el mundo (...).

El cine, por esa especie de universalidad, de catolicidad que propone, invita a la apertura, a la dilatación (...).

El cine puede ofrecernos más todavía. No es solamente la reproducción de ciertos espectáculos que vemos a nuestro alrededor, no es solamente la encarnación de ciertas verdades, ya que puede llegar bastante más lejos y, como un poema, como un cuadro, puede alcanzar un alto valor simbólico62.

Haciendo una síntesis del pensamiento ageliano podríamos establecer las siguientes características del cine "sagrado":

1. Tratamiento de la historia. Lo importante es el mensaje no el cuidado escrupuloso en el tratamiento de la historia, en los detalles minuciosos o en su puesta en escena con rigorismo histórico.

La preocupación de ofrecer una historicidad correcta (...) inhibe de toda eclosión mística63.

La ventaja que ofrece la ficción, desde este punto de vista, es que "permite tematizar, integrar o glorificar una realidad espiritual cuya existencia es fragmentada o diseminada en la vida real"64. un buen medio de "asegurar" la efectividad de la

58 Cfr. AGEL, Henri: ¿El cine tiene alma? Madrid, Rialp, 1958, p. 22.

59 MAGRIS, Claudio El Danubio, Barcelona, Anagrama, 1994 (4ª ed.), p. 38.

60 De ahí el juego de palabras entre "conocer" y "co-nacer", entre "conocimiento" y "co-nacimiento". El conocimiento que da la imagen audio-visual supone, realmente, un nuevo nacer a la realidad que dicha imagen significa. Cfr. un texto imprescindible para comprender esto a base de ejemplos AGEL, Henri: Cinéma et nouvelle noissance, París, Albin Michel, 1981.

61 Cfr. AGEL, Henri: "El humanismo cinematográfico" en VV.AA. Cine, educadores y educandos, Madrid, Sociedad de Educación Atenas, 1961, pp. 63-71.

62 AGEL, Henri: ““"El humanismo cinematográfico” en VV.AA. Cine, educadores y educandos, Madrid, Sociedad de Educación Atenas, 1961, pp. 66-69.

63 AGEL, Henri: El cine y lo sagrado, Madrid, Rialp, 1960, p. 102.

64 BEDOUELLE, Guy: Du spirituel dans le cinéma, París, Cerf, 1985, p. 13. 
historia es recurrir a las obras de arte ya existentes y que son "portadoras" de esa espiritualidad buscada.

Las películas consagradas a las obras de arte son un modo de ilustración mucho más válido de la realidad histórica de lo sagrado. El cinema representa aquí un papel revelador, ilumina plenamente la espiritualidad de que está cargada determinada obra inspirada por el sentimiento religioso65.

Otro buen medio -en la misma línea- es la adaptación cinematográfica de obras de la literatura, siempre que se respete la especificidad del hecho -y del mediocinematográfico y no sea una mera transcripción directa a modo de un "teatro filmado"66.

2. "Interioridad" de la obra. En cuanto a la sintaxis de la imagen, tiene capital importancia la buena utilización de los primeros planos, pues son los que mejor manifiestan la espiritualidad, quedando reducida al mínimo la posibilidad de distraerse con detalles que perjudicarían la inmersión del espectador en la interioridad de la historia que se está narrando y significando. Lo mejor para poder realizar una buena contemplación es que el realizador haya cuidado la "interioridad" de la película, esto es, el esmero en la elección de planos, de recursos cinematográficos, en el montaje de las secuencias. Si no existe esa interioridad es imposible que se manifieste "el alma" de la obra, pues depende, precisamente, del estilo que se adopte. La propia alma del espectador necesita encontrar en las imágenes que la película le ofrece esa "huella" de lo sagrado. Eso el director lo consigue con su estilo que debe crear la "tensión" espiritual necesaria para llevar al espectador -con mirada limpia- al descubrimiento de lo sagrado. Lo que debe conseguir el realizador es "arrastrar" al espectador, conducirlo, a lo invisible que en ese mundo visible de las imágenes subyace en su película y que le debe descubrir lo sagrado que en ella hay.

3. Intemporalidad. La intemporalidad ayuda a no "pegarse", en demasía, a una situación pasada sino a situarnos en presente desde una historia. Tal vez esa historia esté anclada en el pasado pero, para una contemplación estética y espiritual, ese dato temporal debe ser accesorio y, en ningún momento, condicionado de la contemplación. El juego de la temporalidad, para Agel, es un elemento de primer orden.

Es la suya [se refiere Agel a la película de Sjöberg Fröken Julie:] una ubicación espacial y temporal. Así sucede (...) deslizándose constantemente de un momento de la tragedia presente a un momento anterior, mediante un simple desplazamiento de la cámara en el espacio, no nos parece avanzar ni retroceder en el tiempo; unimos esta

\footnotetext{
65 AGEL, Henri: El cine y lo sagrado, Madrid, Rialp, 1960, p. 108.

66 Cfr. AGEL, Henri: "Finalité poétique du cinéma" en SOURIAU, Etienne (et alt.): L'Univers filmique, París, Flammarion, Col. Bibliothèque d'Esthétique, 1953, p. 199.
} 
yuxtaposición temporal que se nos ofrece mediante una yuxtaposición espacial.

Durante algunos segundos, somos presa del vértigo; el tiempo se convierte en un mito 0 , más bien, desaparece: ya no hay más que un eterno presente. Al ofrecernos en un mismo plano dos momentos más o menos alejados uno del otro, al confundir el ayer y el hoy, la pantalla nos introduce en una nueva categoría, casi indispensable para nosotros, la categoría de lo eterno o, por lo menos, de la existencia que toman las cosas ante una contemplación que se ejerce desde lo eterno" 67.

4. De lo concreto a lo cósmico. Lo cotidiano no es una barrera para fundirse en lo espiritual y, por tanto en lo cósmico y universal68. De lo concreto nos podemos elevar a lo cósmico, pues todo nos sirve como signo de una realidad más general y profunda.

Lo eterno (...) se expresa mediante lo cotidiano (...). Pero, en este punto, la reciprocidad del principio estético y espiritual adoptado viene a ejercerse con una eficacia sorprendente: si lo eterno se ha hecho cotidiano, lo cotidiano se hace eterno (...). Al asumir toda la temporalidad, toda la sustancia carnal de una historia humana particular, lo espiritual la dignifica y la transfigura. Se irradia en lo más íntimo y lo dilata en lo intemporal69.

5. Dramatismo. Los elementos dramáticos por antonomasia son los que muestran la vitalidad, la autenticidad de los personajes y de las situaciones, los hacen reales, asequibles al espectador, fácilmente asimilables e identificables con él; es el caso de Kurosawa:

los elementos dramáticos más fuertemente arraigados en el cosmos [son] cuerpos sudorosos, gritos, jadeos, sollozos, presencia casi palpable de la tierra, de las hojas, del aire70.

6. Decoración. Los elementos decorativos sin embargo no deben ocupar un lugar tal que condicionen la visualización. Deben ser estilizados, la sobriedad ayuda, más que el recargamiento, a la contemplación. Siguiendo con Kurosawa:

elementos hieráticos de una poderosa estilización [como son] decorado desnudo del tribunal, espacio reducido del drama, sistemática ultranza de la representación71.

7. Corporalidad de lo sobrenatural. Como se está viendo lo "espiritual" no es únicamente algo fuera, lejano o que no tiene nada que ver con lo material o corporal. No. Lo que sucede es que no se debe quedar ahí, se sirve de esos elementos puesto que los seres humanos somos, también, cuerpo y el cine es imágenes que se

67 AGEL, Henri: El cine y lo sagrado, Madrid, Rialp, 1960, pp. 62-63.

68 Cfr. AGEL, Henri: ¿El cine tiene alma? Madrid, Rialp, 1958, pp. 20-22.

69 AGEL, Henri: El cine y lo sagrado, Madrid, Rialp, 1960, p. 59.

70 AGEL, Henri: El cine y lo sagrado, Madrid, Rialp, 1960, p.48.

71 AGEL, Henri: El cine y lo sagrado, Madrid, Rialp, 1960, p.48. 
nos ofrecen a los sentidos. Los elementos materiales, especialmente el cuerpo, pueden hablarnos de lo espiritual de forma imponente, dependerá de la forma que tengamos de tratarlo, de mostrarlo. Lo que la obra debe ofrecer siempre son imágenes veraces, vitales, expresivas 72.

De todos los elementos de la corporeidad humana, el rostro es el más impactante para la retina del espectador. Una expresión del rostro transmite muchísima información para alguien que está, todo él, pendiente de esa imagen. Para Agel posee, además, una cualidad única con respecto a los demás objetos, ya que para él tiene una espiritualidad intrínseca. El rostro es espiritual de suyo, los demás objetos pueden ser espiritualizados o sobre-elevados de su materialidad, pero no lo son por ellos mismos.

El rostro humano es la parte más espiritual del individuo, la parte gracias a la que el alma es intuida a través de la mirada73.

El rostro es de tal expresividad que es capaz de llenar de sentido la pantalla sin necesidad de palabras, como bien demostró el cine mudo. La imagen cinematográfica, por sí misma, tiene que ser ambigua, esto es, remitir a un polisentido y el rostro ayuda a conseguirlo de forma sorprendente 74 . Esta cualidad es, para Henri Agel, una de las garantías más grandes de la autenticidad de una obra75. La imagen cinematográfica debe ser siempre más visual que sonora.

El cine, minimizando la palabra en aras del rostro, expresándose con un gesto, con un rasgo de la fisonomía, nos conduce plenamente al corazón de lo real (...). El cine nos lleva a sentir, una vez más, que lo esencial está siempre más allá de las palabras (...). En realidad, yo no creo que la palabra sea expresión fiel de nuestra interioridad. Lo principal, lo esencial está siempre más allá del vocabulario y del lenguaje76.

8. Elementos psicológicos. Los elementos psicológicos son importantes porque ayudan a mostrar la interioridad de los personajes y, así facilitan, la profundización en lo significado. La forma que el cine tiene de mostrar esos elementos es, principalmente, por medio de gestos, juegos de fisonomía, movimientos de los personajes y de la cámara, palabras siempre breves y calculadas para que queden

\footnotetext{
72 De hecho el capítulo III del libro de Agel, El cine y lo sagrado lleva el significativo título de "Porque lo sobrenatural es también carnal" (Madrid, Rialp, 1960, pp.56-94).

73 AGEL, Henri: "El cine, nueva dimensión" en VV.AA. Cine, educadores y educandos, Madrid, Sociedad de Educación Atenas, 1961, p. 24

74 Cfr. AGEL, Henri: Greta Garbo, París, Librairie Séguier, 1990, pp. 55-60; como afirma Bedouelle "la sola expresión del rostro daba a comprender los sentimientos más primordiales que conocía el hombre y que todos podían por tanto reconocer: el amor, el odio, la piedad, el desprecio, el pavor, la admiración" (BEDOUELLE, Guy: Du spirituel dans le cinéma, París, Cerf, 1985, p. 16).

75 Cfr. AGEL, Henri: "El cine, nueva dimensión” en VV.AA. Cine, educadores y educandos, Madrid, Sociedad de Educación Atenas, 1961, p. 26.

76 AGEL, Henri: "El cine, nueva dimensión" en VV.AA. Cine, educadores y educandos, Madrid, Sociedad de Educación Atenas, 1961, pp. 26-27.
} 
siempre subordinadas a la apariencia visible. Así como utilizar metáforas visuales apoyadas, muchas veces, en la naturaleza (fugas de nubes, sombras trágicas o voluptuosas, caídas de pétalos, movimiento en unas plantas, viento...), el tiempo atmosférico (lloviznas, días oscuros o inusitadamente luminosos, tempestades y tormentas, contraluces, nieblas -eso sí transparentes-, agua), colores, etc77 Este es el poder del cine y, en general de todo arte:

El arte representa un lado interior y subjetivo del hombre; todas sus estructuras simbólicas son otros tantos esfuerzos por inventar un vocabulario y un idioma mediante los cuales el hombre pueda llegar a externalizar y proyectar sus estados interiores y particularmente, dar forma concreta y pública a sus emociones, sus sentimientos, sus intuiciones de los significados y valores de la vida78.

9. Obra abierta. La película debe ser un sistema abierto de signos, nunca cerrado, pues lo abierto es lo poético, donde puede entrar lo subjetivo. De ahí que la imagen fílmica, si está bien tratada y no encorsetada, por su mismo carácter ambiguo -que es su virtualidad simbólica- es un medio muy idóneo para realizar un arte verdaderamente trascendente. No se trata tanto de la técnica que lo posibilita sino de cómo usamos la técnica para que lo haga posible. Es el uso artístico y no técnico de los medios, aunque esos medios sean técnicos. Es, de hecho, la permanente pugna entrambas.

Porque la esencia de la técnica no es nada técnico, por ello, la meditación esencial sobre la técnica y la confrontación decisiva con ella tienen que acontecer en un ámbito que, por un lado, esté emparentado con la esencia de la técnica, y por otro sea fundamentalmente diferente de ella.

Ámbito tal es el arte. Sin duda, siempre y cuando la meditación artística, por su parte, no se cierre a la constelación de la verdad por la que preguntamos 79 .

10. Genialidad del autor y capacidad del espectador. Con todo no se pueden entender estas "notas" como reglas fijas que todo realizador debe cumplir si desea hacer una película "sobrenatural", esto es, según Agel, buena. Siempre hay otro parámetro que no es en absoluto medible: la genialidad del autor, que es el que traza personalmente la imagen que nos llevará a esa buscada trascendencia, por su virtud propia de símbolo y por la habilidad del realizador en escribir en la imagen que se desarrolla en la temporalidad de la proyección.

Cfr. SOURIAU, Etienne: La peinture et l'espace: Recherche sur les conditions formelles de l'expérience esthétique, París, Presses Universitaires de France (P.U.F.) pp. 26-27.

78

MUMFORD, Lewis: Arte y técnica, Buenos Aires, Nueva Visión, 1968, pp. 36-37. 1994, p. 29.

HEIDEGGER, Martin, "La pregunta por la técnica" en Conferencias y artículos, Barcelona, Ediciones del Serbal, 
Cada vez que la intuición de la trascendencia se ha expresado según líneas de fuerza vivas y personales, el desarrollo de una película nos ha dejado entrever el cumplimiento incesantemente renovado del misterio que integra la muerte en la vida y lo temporal en la eternidad. Pero, más allá de los modos de expresión más eficaces, el lenguaje cinematográfico en sí mismo, ¿no puede parecer investido de una alta finalidad espiritual?80

Pero la "genialidad" del realizador para contarnos la película debe, como ya hemos visto, acompañarse de la capacidad del espectador de "entender" dicho mensaje y poder extraer sus sentidos. Matizando esta visión ageliana, Jean Mitry rebaja el planteamiento metafísico haciéndolo revertir en un problema psicológico:

Por el contrario, el mundo visto en la pantalla se revela en una especie de plenitud "cósica". Pero no descubre virtudes singulares más que porque es consecuencia de una mirada y esa mirada le da un sentido inmediatamente perceptible, debido al hecho mismo de que "mirar el mundo" es aislar una de sus caras, ver uno de sus aspectos con exclusión de todos los demás. En cine vemos lo que otro ya ha "visto".

La imagen cinematográfica no es "imagen del mundo", sino un aspecto del mundo. Distingue los objetos y sus relaciones según un punto de vista que implica relaciones referidas a ese punto de vista y a las limitaciones del "campo. 81

Si anteriormente marcábamos tres niveles de posibilidades en el cine con alma82 ahora podemos señalar tres inconvenientes que debe evitar todo cine que pretenda ser sobrenatural.

Primero, el aplastamiento del tema bajo la fastuosidad grandilocuente de una reconstrucción histórica, que ofrece el doble defecto de tomar el tema desde el exterior (desde el punto de vista 'espectáculo') y de alejarle peligrosamente de nosotros por su historicidad.

Segundo, el recurso a la poetización sulpiciana que embadurna el guión, los rostros, los decorados y los sucesos del mismo barniz dulzón y blando, y adopta el estilo de una postal bien intencionada.

Tercero, la indecisión estética y dramática acerca del estilo que hay que elegir, haciendo oscilar la película entre el documental, el discurso edificante, la epopeya y el "trozo de vida" realista83.

\footnotetext{
80 AGEL, Henri: El cine y lo sagrado, Madrid, Rialp, 1960, p. 110.

81 MITRY, Jean: Estética y psicología del cine, Vol. 2: "Las formas", Madrid, Siglo XXI, 1986, p. 507.

82 A saber, la transformación de lo real, la en-raización del ser humano en su espacio-tiempo (folklore) y la captación de acontecimientos humanos ordinarios en los cuales hay una huella cosmológica.
} 
Es decir, el tema no es garante de conseguir un cine con alma. Las superproducciones de Hollywood sobre temas "piadosos" son un buen ejemplo. Agel es implacable en su juicio tremendamente negativo sobre este tipo de cine que, vale la pena caer en la cuenta, abarca, para él, casi toda la producción. Baste recordar su "condena" total a la película Joan of Arc de Victor Fleming (1948). Agel no puede perdonar la manipulación del medio so pretexto de un fin "bondadoso" o "piadoso".

La hagiografía explícita, el film histórico consciente de serlo, el sermón en imágenes, ¿no serán géneros falsos, categorías en el fondo impensables en el dominio de un arte sagrado cinematográfico?84

Para Agel son absolutamente incompatibles los "servilismos" morales y/o espirituales con un cine verdaderamente sagrado. Para él es válido un cine "como medio de expresión de lo espiritual", pero nunca un cine "como simple vehículo de lo espiritual"; se debe saber expresar lo espiritual de forma válida (artística), "deben ser el propio desarrollo de la historia, su autenticidad plástica, dramática, melódica incluso, las que hagan que el film sea un testimonio eficaz" 85 . Igual que no todo tema es, de suyo, capaz de convertir una película en cine sagrado, tampoco todo sentimiento es de suyo espiritual, en el sentido que venimos diciendo, ni tampoco todo sentimiento es un valor vital. Todo sentimiento es un valor pero para que sea un valor vital debe acarrear, consigo, un compromiso, una respuesta, en la que uno se implica y se da. Para Agel el sentimiento vacío y fácil, es decir, el puro sentimentalismo, es deleznable. Es preferible, como ya se ha visto, una película que se dedique a filmar una obra de arte que ese tipo de realizaciones que imposibilitan, per se, cualquier arranque de trascendencia. Estas otras películas, por lo menos, cuentan con lo que les aportan las obras que filman, ya es algo, evitan la total esterilidad. Por lo tanto nunca se debe equivocar el juicio sobre lo sobrenatural por el uso del tema. Tampoco es bueno buscar una lista de normas -una especie medida sacra para, como si de una receta se tratase, ver o realizar auténtico cine con alma. Hay que trabajarse la realización y la contemplación.

\section{Referencias}

AGEL, Henri y Geneviève Agel: Manual de iniciación cinematográfica, Madrid, Rialp, 1958 (3를. 1965), p. 33.

AGEL, Henri: ¿El cine tiene alma? Madrid, Rialp, 1958, pp. 31-36.

AGEL, Henri: ““El humanismo cinematográfico” en WV.AA. Cine, educadores y educandos, Madrid, Sociedad de Educación Atenas, 1961, pp. 66-69.

AGEL, Henri: "Finalité poétique du cinéma" en SOURIAU, Etienne (et alt.): L'Univers filmique, París, Flammarion, Col. Bibliothèque d’Esthétique, 1953, p. 199.

AGEL, Henri: El cine y lo sagrado, Madrid, Rialp, 1960, p. 102. 
AGEL, Henri: El cine. Bilbao, Desclée de Brouwer, 1957, pp. 134-135.

AGEL, Henri: Estética del cine, Buenos Aires, Eudeba, 1962 (2ª̂ad. 1968), pp. 5-6.

AGEL, Henri: Greta Garbo, París, Librairie Séguier, 1990

AGEL, Henri: Métaphisique du cinéma, París, Petite Bibliothèque Payot, 1976.

AGEL, Henri: Poétique du cinéma, París, Ed. du Signe, 1973, 61ss.

AGEL. Henri: El cine. Bilbao, Desclée de Brouwer, 1957, pp. 20-24.

Amédée Ayfre, "Neo-Réalisme et Phenomenologie" en Cahiers du Cinéma, 1952, n. 17.

ANDREW. Dudley J.: Las principales teorías cinematográficas, Madrid, Rialp (2ed. aumentada; $1^{\text {a }}$ ed. en Barcelona, Gustavo Gili, 1978), pp. 292.

ANDREW. Dudley J.: Las principales teorías cinematográficas, Madrid, Rialp (2e․ aumentada; $1^{\text {a }}$ ed. en Barcelona, Gustavo Gili, 1978), p. 288.

ANDREW. Dudley J.: Las principales teorías cinematográficas, Madrid, Rialp (2e․aumentada; $1^{\underline{a}}$ ed. en Barcelona, Gustavo Gili, 1978), p. 239/291.

AYFRE, Amédée: El cine y la fe cristiana, Andorra, Casal i Vall, 1962, p. 118.

BEDOUELLE, Guy: Du spirituel dans le cinéma, París, Cerf, 1985, p. 13.

Cfr., p.e., "El cine como mediación" en "Cine y presencia personal", dentro del libro colectivo AGEL, Henri y AYFRE, Amédée: Cine y personalidad, Madrid, Rialp, 1963, pp. 64-68.

CHENU, Joseph: Le thèâtre de G. Marcel et sa signification mètaphysique, Aubier, 1948; sic AYFRE, Amédée: Cinéma et mystère, París, Cerf, 1969, p. 121.

HEIDEGGER, Martin, "La pregunta por la técnica" en Conferencias y artículos, Barcelona, Ediciones del Serbal, 1994, p. 29.

Jean Claude Renard "Retour au sacré" en La Nef, juio-julio 1951 sic AGEL, Henri: El cine y lo sagrado, Madrid, Rialp, 1960, p. 14.

MAGRIS, Claudio El Danubio, Barcelona, Anagrama, 1994 (4ª ed.), p. 38. 
MITRY, Jean Intèrmedes, n. 1 sic AGEL, Henri: El cine y lo sagrado, Madrid, Rialp, 1960, p. 25.

MITRY, Jean: Estética y psicología del cine, Vol. 2: “Las formas", Madrid, Siglo XXI, 1986, p. 507.

MUMFORD, Lewis: Arte y técnica, Buenos Aires, Nueva Visión, 1968, pp. 36-37.

SOURIAU, Etienne: La correspondencia de las artes: Elementos de estética comparada, México: F.C.E., 1986 (1aㅡ ed.: 1965), p. 90.

SOURIAU, Etienne: La peinture et l'espace: Recherche sur les conditions formelles de l'expérience esthétique, París, Presses Universitaires de France (P.U.F.) pp. 26-27.

STEINER, George: Presencias reales. ¿Hay algo en lo que decimos?, Barcelona, Destino, 1991, pp. 14, 111-113, 164, 121, 124, 149, 253 у 272-277.

ZURIAN, Francisco A. y ZARCO, Alejandro "El arte y la cultura tecnológica" en Quaderns de Filosofia i Ciència, nn. 21-22, 1993,

ZURIAN, Francisco A.: "Entrevista con Henri Agel: Por una teoría del cine" en FilmHistoria, Vol. I, no 1, 1991, p. 39-41.

ZURIAN, Francisco A.: "Entrevista con Henri Agel: Por una teoría del cine" en FilmHistoria, Vol. I, no 1, 1991

ZURIAN, Francisco A.: "Lo real, lo imaginario y lo insinuado. Notas en torno a Henri Agel" en Quaderns de Filosofia i Ciència, nn. 13-14, 1988 